\title{
A parallel universe where psychiatry is like the rest of medicine
}

Received 6 November 2017; Accepted 7 November 2017; First published online 4 December 2017

Key words: Antidepressants, antipsychotics, mental illness stigma, psychopharmacology, psychotropic drugs.

Commentary on: Moncrieff J (2017). Research on a 'drug-centred' approach to psychiatric drug treatment: assessing the impact of mental and behavioural alterations produced by psychiatric drugs. Epidemiology and Psychiatric Sciences. doi: 10.1017/S2045796017000555.

Sometimes I wish I were Will Parry in Philip Pullman's His Dark Materials. I wish I could use a knife to cut across dimensions and move into a parallel universe. A parallel universe where myself, Joanna Moncrieff, the Critical Psychiatry Network, the Royal College of Psychiatrists, and the other mental health clinical, scientific and advocacy organisations, are all together on the same side of the barricades, and together we face our common enemies. Because we have many common enemies.

First and foremost, we face the stigma and discrimination that affects not only people with mental health problems but also the psychiatrists and mental health professionals that are trying to help them. The percentage of medical doctors that are training to become psychiatrists can be counted on less than one hand's fingers. Second, we face the continuing and relentless shrinking of resources dedicated to mental health services across the world, leading to a never-ending stream of news headlines, but no change in direction from governments. The waiting lists for first assessments, let alone psychotherapeutic interventions, are months-long. Third, we face a lack of effective pharmacological interventions for the many people that cannot tolerate, or do not benefit from, currently available medications; and yes, these medications are imprecise and unsatisfactory, but are the best we have until we find some new ones; and we are not going to find new medications soon, since all major pharmaceutical companies have withdrawn from research and development in psychiatry.

Yet, in this universe where I am living now, we often find ourselves - mental health clinicians,

Address for correspondence: C. M. Pariante, Institute of Psychiatry, Psychology and Neuroscience, King's College London, London, UK. (Email: carmine.pariante@kcl.ac.uk) academics and organisations - on the opposite sides of the barricades. Even when there are no barricades, we create them by formulating models for which we have to be in favour or against. I have argued before, in both this journal (Pariante, 2016) and in the Huffington Post (Pariante \& Rose, 2016), that there are no barricades between the 'biomedical' and the 'psychosocial' approaches to psychiatry. Here I will argue that there are no barricades between the 'drugcentred' and the 'disease-centred' approaches: Joanna Moncrieff is right in what she writes in this journal (Moncrieff, 2017), and I am really glad that she has written this paper. In fact, I wish we were in the other universe, and I wished we had written this paper together. I also wish that, together, we had discussed how this philosophical debate on the drugcentred $v$. disease-centred approach is not at all specific to psychiatry but it extends to all aspects of medicine and health.

Because there is no difference between medicine and psychiatry, and nothing has changed since the beginning of times, when our ancestors first used latex from the opium poppy and leaves from the Salix tree. We have a body (which includes a brain) that feels changes in functions or sensations or emotions (symptoms), which sometimes other people can see (signs), and that can be induced, or modified, by external agents: the poison of a snake; the deadly effect of a bacterium; the extract of a leave; the assault of a predator; the ruthlessness of discrimination or the chemical product of a pharmaceutical plant. Nothing more, nothing less.

Of course, Joanna is right that we are using psychotropic medications to affect biochemical systems that may not be directly implicated in the disease mechanism of the (mental) disorder for which they are prescribed. As I have said before (Pariante, 2017a), the original idea that antidepressants 'correct a chemical imbalance in the brain' is an oversimplification. But, in terms of therapeutic interventions, this is not different from what we do when we give an antiinflammatory drug to people with infections: the underlying disease mechanism (a virus or a bacteria) 
has nothing to do with the inflammatory system, and we just want to control the symptoms and the signs. We and others are testing anti-inflammatory drugs to treat depression: this is targeting a biochemical system in the body, to induce downstream effects in the brain, to eventually affect processes relevant to depression. How is this different from the rest of medicine?

Anti-inflammatory drugs create an altered physiological state in immune function, so much so that they can induce side effects in the opposite directions of the therapeutic effect: used to treat the deleterious effects of infections, these drugs can make things worse in a minority of sensitive individuals by reducing the immune system's ability to fight infections. Anti-cancer drugs also do the same, because they treat cancer by creating an altered physiological state in cells replication. In fact, these drugs can cause other cancers, while treating the one for which they are prescribed, exactly because they affect a physiological mechanism which is present in all cells, not just the diseased one. How is this different from psychiatry?

One more consideration. The potential harm induced by anti-cancer drugs (and by many other classes of drugs) is much worse than that induced by psychotropic medications. Anti-cancer drugs can kill people while trying to save them, or while successfully saving others: they come in brightly labelled boxes with death warnings. The cardiac death risk associated with certain antibiotics is as high as 5 per 1000 person years. Why there is no public outcry against these drugs, no press campaigns, no 'anti-oncology' or 'antiantibiotics' movements? Is this because these drugs treat 'deadly illnesses', and thus all risks are acceptable? But psychotropic medications also treat deadly illnesses: even not accounting for the impairment in quality of life that makes mental disorders among the top leading causes of burden both in the developing and the developed world, close to one million people die from suicide every year: one death every $40 \mathrm{~s}$. By 2020, it will be one death every $20 \mathrm{~s}$. Why cannot we accept that psychotropic medications are like all other drugs in medicine: overall beneficial, but with side effects that sometimes are severe and in very rare circumstances are tragic (Pariante, 2017a, b, c).

Finally, Joanna is right that we should do all the studies that she suggests. We should do biological, clinical and phenomenological studies on the effects of psychotropic medications, in healthy volunteers and clinical samples, both short-term and long-term. We should also pursue animal models to understand more of what these medications do. I have done exactly this kind of studies myself (Pariante et al. 2004, 2012; Anacker et al. 2011, 2013; Mason et al. 2011; Cattaneo et al. 2013; Horowitz et al. 2014). But the question is: how will we pay for it? I have already mentioned the lack of interest from pharmaceutical companies in mental health research. In terms of public research funding per person affected, approximately 100 times more money is spent on cancer than on mental health; and in terms of philanthropy, the United States public donates five times more money to cancer than to mental health research, and for the United Kingdom public, the equivalent figure is a staggering 900 times more (Krystal et al. 2016). So yes, we should do all of these studies. But, if we have to prioritise resources, shouldn't we try to find new and better drugs?

Now I wish I were William Parry again, and cut my way into yet another parallel universe. This is a universe where there are new psychotropic medications. They are effective and well tolerated, and in this universe people talk about serotonin reuptake inhibitors and anti-dopaminergic drugs as old remedies used many generations before. Rumour has it that the next Pullman's novel is a sequel to His Dark Materials. Perhaps it will feature such a universe.

\section{Acknowledgement}

CMP is supported by the UK National Institute for Health Research (NIHR) Biomedical Research Centre at the South London and Maudsley NHS Foundation Trust and King's College London; and by the UK Medical Research Council, grants MR/L014815/1 and $\mathrm{MR} / \mathrm{J} 002739 / 1$. CMP has received research funding from pharmaceutical companies interested in the development of new antidepressants, such as Johnson \& Johnson and Eleusis Ltd, but this amounts to $<10 \%$ of his overall research funding. Moreover, he has received research funding from the Medical Research Council (UK) and the Wellcome Trust for research on depression and inflammation as part of two large consortia that also include Johnson \& Johnson, GSK, Pfizer and Lundbeck. He has no conflict of interests with regards to Philip Pullman's books, except that at the time of writing this article he was reading Pullman's recently published La Belle Sauvage.

C. M. Pariante
Institute of Psychiatry, Psychology and Neuroscience,
King's College London, London, UK

\section{References}

Anacker C, Zunszain PA, Cattaneo A, Carvalho LA, Garabedian MJ, Thuret S, Price J, Pariante CM (2011). Antidepressants increase human hippocampal neurogenesis by activating the glucocorticoid receptor. Molecular Psychiatry 16(7), 738-750. 
Anacker C, Cattaneo A, Musaelyan K, Zunszain PA, Horowitz M, Molteni R, Luoni A, Calabrese F, Tansey K, Gennarelli M, Thuret S, Price J, Uher R, Riva MA, Pariante CM (2013). Role for the kinase SGK1 in stress, depression, and glucocorticoid effects on hippocampal neurogenesis. Proceedings of the National Academy of Sciences of the USA 110(21), 8708-8713.

Cattaneo A, Gennarelli M, Uher R, Breen G, Farmer A, Aitchison KJ, Craig IW, Anacker C, Zunsztain PA, McGuffin P, Pariante CM (2013). Candidate genes expression profile associated with antidepressants response in the GENDEP study: differentiating between baseline 'predictors' and longitudinal 'targets'. Neuropsychopharmacology 38(3), 377-385.

Horowitz MA, Wertz J, Zhu D, Cattaneo A, Musaelyan K, Nikkheslat N, Thuret S, Pariante CM, Zunszain PA (2014). Antidepressant compounds can be both pro- and anti-inflammatory in human hippocampal cells. International Journal of Neuropsychopharmacology 18(3).

Krystal JH, Abi-Dargham A, Akbarian S, Arnsten AFT, Barch DM, Bearden CE, Braff DL, Brown ES, Bullmore ET, Carlezon WA Jr., Carter CS, Cook EH Jr., Daskalakis ZJ, DiLeone RJ, Duman RS, Grace AA, Hariri AR, Harrison PJ, Hiroi N, Kenny PJ, Kleinman JE, Krystal AD, Lewis DA, Lipska BK, Marder SR, Mason GF, Mathalon DH, McClung CA, McDougle CJ, McIntosh AM, McMahon FJ, Mirnics K, Monteggia LM, Narendran R, Nestler EJ, Neumeister A, O'Donovan MC, Öngür D, Pariante CM, Paulus MP, Pearlson G, Phillips ML, Pine DS, Pizzagalli DA, Pletnikov MV, Ragland JD, Rapoport JL, Ressler KJ, Russo SJ, Sanacora G, Sawa A, Schatzberg AF, Shaham Y, Shamay-Tsoory SG, Sklar P, State MW, Stein MB, Strakowski SM, Taylor SF, Turecki G, Turetsky BI, Weissman MM, Zachariou V, Zarate CA Jr., Zubieta JK (2016). Constance E. Lieber, Theodore R. Stanley, and the enduring impact of philanthropy on psychiatry research. Biological Psychiatry 80(2), 84-86.
Mason BL, Thomas SA, Lightman SL, Pariante CM (2011). Desipramine treatment has minimal effects on the brain accumulation of glucocorticoids in P-gp-deficient and wild-type mice. Psychoneuroendocrinology 36(9), 1351-1360.

Moncrieff J (2017). Research on a 'drug-centred' approach to psychiatric drug treatment: assessing the impact of mental and behavioural alterations produced by psychiatric drugs. Epidemiology and Psychiatric Sciences, This Issue.

Pariante CM (2016). Neuroscience, mental health and the immune system: overcoming the brain-mind-body trichotomy. Epidemiology and Psychiatric Sciences 25(2), 101-105.

Pariante CM (2017a). Antidepressants may not be perfect, but they DO save lives. The Daily Mail. 20 February 2017. http://www.dailymail.co.uk/health/article-4243156/ Antidepressants-not-perfect-save-lives.html

Pariante CM (2017b). Do Antidepressants Save Lives? A Comment On The 2016 Interim Report On Suicide Prevention By The House of Commons Health Select Committee. The Huffington Post. 6 February 2017. http:// www.huffingtonpost.co.uk/carmine-pariante/ do-antidepressants-save-1_b_14616018.html

Pariante CM (2017c). Panorama's prescription. Lancet Psychiatry 4(9), e21. doi: 10.1016/S2215-0366(17)30312-7.

Pariante CM, Rose N (2016). There Are More Connections in the Human Brain Than There Are Stars in Our Milky Way Galaxy... The Huffington Post. 17 May 2016. http://www. huffingtonpost.co.uk/carmine-pariante/ there-are-more-connections_b_9980694.html

Pariante CM, Papadopoulos AS, Poon L, Cleare AJ, Checkley SA, English J, Kerwin RW, Lightman S (2004). Four days of citalopram increase suppression of cortisol secretion by prednisolone in healthy volunteers. Psychopharmacology 177(1-2), 200-206.

Pariante CM, Alhaj HA, Arulnathan VE, Gallagher P, Hanson A, Massey E, McAllister-Williams RH (2012). Central glucocorticoid receptor-mediated effects of the antidepressant, citalopram, in humans: a study using EEG and cognitive testing. Psychoneuroendocrinology 37(5), 618-628. 